\title{
NEUROLOGICAL COMPLICATIONS OF PANDEMIC COVID-19: What have we got so far?
}

Isabelle Pastor Bandeira1; Marco Antônio Machado Schlindwein1; Leticia Caroline Breis'; Jean Pierre Schatzmann Peron2,3,4 ; Marcus Vinícius Magno Gonçalves ${ }^{5}$

1- Medical student - Department of Medicine, Universidade da Região de Joinville (UNIVILLE), Brazil. 2- Professor and Ph.D. - Department of Immunology, Institute of Biological Sciences, Universidade de São Paulo (ICB-USP), São Paulo, Brazil.

3 -Scientific Platform Pasteur-USP, University of São Paulo (USP), São Paulo, SP. CEP 05508-020, Brazil.

4 - Immunopathology and Allergy Post Graduate Program, School of Medicine, University of São Paulo (USP), São Paulo, SP CEP 01246-903 Brazil.

5 - Medical Doctor, Ph.D., and Professor of Neurology, Universidade da Região de Joinville (UNIVILLE), Brazil.

\section{Corresponding Author}

Dr. Marcus Vinícius Magno Gonçalves

Department of Medicine - University of the Region of Joinville. Paulo Malschitzki, 10 - Zona Industrial Norte, CEP 89201-972, Joinville, Santa Catarina, Brazil. Phone number: +55 479 9974-9668. E-mail: marcusribeirao@yahoo.com.br

\section{Study funding}

JPSP is funded by FAPESP grants \#2017/26170-0 and 2017/22504-1 and CNPq (301287/2016-3). No other targeted funding reported.

\section{Keywords}

COVID-19; SARS-CoV-2; NEUROLOGY; CORONAVIRUS;

Title character count: 73

Abstract word count: 147

Manuscript word count: 2734

Number of References: 51

Number of tables: 1

Appendix: 1 


\section{Disclosure}

The authors report no disclosures. All authors and contributors agree to the conditions outlined in the Authorship and Contributorship section of the Information for Authors. The authors have read the Journal's position on issues involved in ethical publication. There was no sponsorship for the scientific article and there was no conflict of interest with all the authors. 
Abstract:

The recently emerged coronavirus named Severe Acute Respiratory Syndrome Coronavirus 2 (SARSCoV-2) is the newest threat to human health. It has already infected more than half a million people worldwide, leading to a lot of deaths. Although it causes mild flu-like disease in most patients, lethality may increase to more than $20 \%$ in elderly subjects, especially those with comorbidities, like hypertension, diabetes or lung and cardiac disease, and the mechanisms are still elusive. Common symptoms at the onset of illness are fever, cough, myalgia or fatigue, headache, and diarrhea or constipation. Interestingly, respiratory viruses have also placed themselves as relevant agents for CNS pathologies. Here we discuss several CNS related features, referred by several patients, especially at the beginning of the disease. Thus, we also discuss the possibility by which SARS-CoV-2 may affect the olfactive system of patients, either directly or indirectly. 


\section{Abbreviations}

SARS-CoV-2 = Severe Acute Respiratory Syndrome Coronavirus 2

COVID-19 = Coronavirus Disease 2019

SARS-CoV $=$ Severe Acute Respiratory Syndrome Coronavirus

SARS $=$ Severe Acute Respiratory Syndrome

MERS = Middle-East Respiratory Syndrome

CNS $=$ central nervous system

hRSV = human respiratory syncytial virus

hMPV = human metapneumovirus

$\mathrm{SP}$ or $\mathrm{S}$ protein $=$ spike proteins

ACE2 $=$ angiotensin-converting enzyme 2

DPP4 = dipeptidyl peptidase 4

CD147 = CD147-spike protein

CoVs $=$ coronaviruses

HCoV-OC43 = human coronavirus OC43

$M H V=$ Murine Hepatitis Virus

$\mathrm{RBD}=$ receptor-binding domain

$\mathrm{CTSB}=$ Cathepsin $\mathrm{B}$

$\mathrm{CTSL}=$ Cathepsin L

OSN = Olfactory Sensory Neurons

$\mathrm{GBC}=$ Globose Basal Cells

$\mathrm{HBC}=$ Horizontal Basal Cells

$\mathrm{PNS}=$ peripheral nervous system

$\mathrm{CSF}=$ cerebrospinal fluid

ADEM = acute disseminated encephalomyelitis 


\section{MANUSCRIPT}

\section{Background}

Viral respiratory diseases are among the most critical problems in public health, as every year they are responsible for high rates of morbidity and mortality (Bohmwald et al. 2018). The recently emerged coronavirus named Severe Acute Respiratory Syndrome Coronavirus 2 (SARS-CoV-2) is the newest threat to human health. It has already infected more than half a million people worldwide, leading to around 90000 deaths. Since December of 2019, the first cases of pneumonia started to be documented in Wuhan - China (Bohmwald et al. 2018; Guan W, et al. 2020). SARS-CoV-2 is an enveloped non-segmented positive-sense RNA virus that belongs to the Coronaviridae family (Huang C, et al. 2020), closely related to previous coronaviruses of medical relevance, as SARS-CoV and MERS-CoV. Due to the fast spread and lethality, the World Health Organization (WHO) officially declared State of Public Health Emergency of International Concern in February 2020 due to the Coronavirus Disease 2019 (COVID-19) (Baig A, et al. 2020; Qin C, et al. 2020).

Although it causes mild flu-like disease in most patients, lethality may increase to more than $20 \%$ in elderly subjects, especially those with comorbidities, like hypertension, diabetes or lung and cardiac disease (Sun D, et. al 2020), and the mechanisms are still elusive (Pinto B, et al. 2020). Viral replication in lung tissue leads to both direct as well as indirect pathology, mainly due to an exacerbated immune response and the cytokine storm produced (Qin C, et al. 2020). Common symptoms at the onset of illness are fever, cough, myalgia or fatigue, headache, and diarrhea or constipation. (Huang C. et al. 2020; Sun D, et. al 2020). Severe cases rapidly evolve to pneumonia with ground-glass opacity observed after lung imaging, evidencing lung infiltration and edema.

Interestingly, respiratory viruses have also placed themselves as relevant agents for central nervous system (CNS) pathologies, such as the human respiratory syncytial virus (hRSV) (Morichi S, et al. 2009) or the human metapneumovirus (hMPV) (Schildgen O, et al. 2005). In fact, several studies have described the association between respiratory viral infections with neurological symptoms, as febrile or afebrile seizures, status epilepticus, encephalopathies, and encephalitis. (Bohmwald et al. 2018). Conversely, during the recent SARS-CoV-2 epidemic, several patients have referred to the loss of the sense of smell and taste during hospitalization. This may be an important feature of the COVID-19, but it is still poorly understood. Thus, here we discuss the possibility by which SARS-CoV-2 may affect the olfactive system of patients, either directly or indirectly.

\section{SARS-CoV-2 and Nervous System}

Coronaviruses invade host cells through the interaction of spike proteins (SP) with membrane receptors as angiotensin-converting enzyme 2 (ACE2) (Hoffmann M, et al. 2020), dipeptidyl peptidase 4 (DPP4) (Raj V, et al. 2013) and most recently, CD147 (Wang K, et al. 2020). After attachment, virus 
particles are internalized, fused with the cell membrane and RNA genome is released within the cytoplasm for protein translation and replication. In this context, viral tropism intimately correlates with the expression of the aforementioned receptors throughout the body (Baig A, et al. 2020).

Conversely, coronaviruses (CoVs) are not always confined to the respiratory tract, as they may also invade intestine (Leung W, et al. 2003), heart tissue (Dimitrov D, 2003; Gu J, 2007; Oudit G, et al. 2009), and central nervous system (Ding Y, et al. 2004; Xu J, et al. 2005; Gu J, et al. 2005). It is already known, for example, that the human coronavirus OC43 (HCoV-OC43), manages to gain access to the CNS through axonal transport and neuron-to-neuron propagation in experimental models (Dubé M, et al. 2020). Interestingly, HCoV-43 viral loads in the brain of C57BI/6 mice reached the same levels when intra-cranioventricular and intranasal delivery were compared. The inoculation of $10^{4} \mathrm{TCID}_{50}$ led to a time-dependent increase in brain viral load. Moreover, viral N proteins were detected by immunofluorescence, evidencing viral migration through the neurons. Noteworthy, viral proteins were detected until 5 days after infection (Dubé M, et al. 2020).

It is believed that SARS-CoV may reach the Central Nervous System via general circulation (through blood-brain barrier) or via olfactory bulb (anatomic related to the cribriform plate and the CNS), as previously demonstrated in mice by Bleau C, et al. (2015) and Netheland J, et al. (2008) ((Baig A, et al. 2020; Bleau C, et al. 2015; Netheland J, et. al. 2008). Additionally, it has been shown that Murine Hepatitis Virus (MHV), a type of coronavirus, may reach the SNC after intranasal delivery. Moreover, the ablation of the olfactory nerve cells abrogated CNS infection after nasal inoculation of the murine hepatitis virus (MHV) (Perlman S, et al. 1990). Subsequently, endothelial damage can also facilitate virus access (Baig A, et al. 2020).

Spike protein (S protein) is the portion of SARS-CoV that interacts with high affinity to human ACE2 on target cells through its receptor-binding domain (RBD) (Baig A, et al. 2020; Hulswit R, 2016; Li W, et al. 2005). S protein is divided in S1 subunit, which is involved in receptor recognition, and S2, which is involved in membrane fusion (Hulswit R, 2016; Li W, et al. 2005); and must be cleaved to properly interact with ACE2, which usually happens by TMPRRS2 protease, Cathepsin B (CTSB) or Cathepsin L (CTSL) (Brann D, et al. 2020). SARS-Cov-2 interaction with ACE2 receptors in neurons leads to neuronal damage without wide inflammation (Baig A, et al. 2020).

The olfactory epithelium is mainly composed by Olfactory Sensory Neurons (OSN; responsible for odor detection and transmission to the brain (Brann D, et al. 2020) ), Globose Basal Cells (GBC; responsible for neurogenesis, renewing olfactory epithelium and neurons (Choi R, et. al. 2018; Fletcher R, et. al 2017), Horizontal Basal Cells (HBC; quiescent cells, stem cells reservoir (Fletcher R, et. al 2017)) and sustentacular cells (structural support for olfactory sensory neurons) (Brann D, et al. 2020). Olfactory Sensory Neurons axons synapse in the olfactory bulb, passing through the cribriform plate (Choi R, et al. 2018) 
As demonstrated by Brann et. al, ACE2 and TMPRSS2 are not expressed in mature Olfactory Sensory Neurons; but in sustentacular cells and HBCs instead, which are believed to be the target cells of CoV-2 infection (Brann D, et al. 2020). Thus, infection of sustentacular cells and HBCs may damage OSNs and impair neurogenesis, resulting in anosmia.

As above mentioned, a possible pathway for viruses to infect the CNS is through the olfactory bulb (Durrant D, et al. 2016; Doty R, et al. 2019; Wen P, et al. 2019). Olfactory Sensory Neurons connect the nasal cavity to the CNS by the axons, which terminate in the olfactory bulb, passing through the cribriform plate (Durrant D, et al. 2016). On the other hand, Olfactory Bulb receives dense innervation from higher brain areas and process odor information (Wen P, et al. 2019); and is possibly infected by coronaviruses (Brann D, et al. 2020). Therefore, as mentioned by Brann D, et. al 2020 the olfactory deficits may occur due to other mechanisms than olfactory epithelium damage; such as higher-order olfactory structures affection (Brann D, et al. 2020).

Although there is no evidence of the presence of SARS-CoV-2 in CNS tissue of affected patients due to lack of a necropsy study evaluating brain tissue, there is evidence of CNS presence of SARS-CoV in brain tissue of patients presenting with SARS in the early 2000s (Ding Y, et al. 2004; Xu J, et al. 2005; Gu J, et a.l 2005). Gu J and colleagues (2005) documented remarkable findings: virus RNA of SARS-CoV infection in the brain of all the 8 autopsies patients they studied; 6 out of this 8 was also found scattered red degeneration and edema on this patients neurons, the findings were restricted to the cytoplasm of neurons on the hypothalamus and cortex (Gu J, et al. 2005).

In addition, $\mathrm{Xu} \mathrm{J}$ et. al (2005) reported a case of a 39-year-old doctor that was in contact with SARSCoV patients and started to experience fever, chills, malaise, dizziness, myalgia when he was admitted to the hospital. After 35 days of illness onset, he passed away due to multiple organ failure and brain herniation. The autopsy revealed SARS-CoV DNA in the patient brain ( $\mathrm{Xu} \mathrm{J}$, et al. 2005). Ding and colleagues (2004), while examining tissue samples from four SARS-Cov patients autopsy, found in all of their four patients evidence of virus infection on the cerebrum, pituitary gland, but not in the cerebellum (Ding Y, et al. 2004).

Besides these, we reiterate that there are still other shreds of evidence of human coronavirus in the human brain. Arbour N, et al. (2000) described the presence of coronaviruses RNA in autopsied brain samples from patients with multiple sclerosis, and other neurological diseases (Alzheimer's, Parkinson's, schizophrenia, depression, and meningoencephalitis) (Arbor N, et al. 2000).

\section{Neurological Manifestations of COVID-19}


The manifestations of neurological symptoms in patients with COVID-19 involve the CNS, peripheral nervous system (PNS) and the skeletal muscles. Severe patients commonly had neurologic symptoms manifested as acute cerebrovascular diseases, consciousness impairment, and muscle injury, leading to a poor prognosis. (Mao L., et al. 2020). In a study carried by Chen and colleagues $22 \%$ of those who died presented with impaired consciousness compared with only $1 \%$ of the patients that survived (Chen T, et al. 2020).

Central Nervous System symptoms, such as headache, dizziness, impaired consciousness, ataxia, acute cerebrovascular disease, and epilepsy, were the main form of neurological injury in patients with COVID- 19 appearing in 53 out of 218 ( 24.8\%) patients in a Chinese cohort (Mao L., et al. 2020). Interestingly, patients presenting CNS involvement were associated with a more severe course of the disease (Mao L., et al. 2020). On the other hand, PNS involvement occurs in 19 patients (8.9\%) and hyposmia and dysgeusia were the most common symptom affecting $11(5.1 \%)$ and 12 (5.6\%) respectively; no laboratory differences were found in patients with or without PNS involvement (Mao L., et al. 2020).

Hwang C described, in 2006, a case of complete anosmia three weeks after the onset of the first symptoms of SARS-CoV infection. The patient was a 27 years-old woman who presented with fever, cough, headache, myalgia, and diarrhea. Three weeks later, after upper respiratory tract improvement, the patient had complete anosmia, for all kinds of smell, on both sides of the nasal cavity. Although no abnormal findings that might cause anosmia were found on physical examination or brain MRI, this symptom persisted for the two years follow-up without changes (Hwang C, 2006). As far as we know, this is the first case report of persisting anosmia after coronavirus infection. Further investigation and patients follow up are necessary to confirm this hypothesis.

Hyposmia is also gaining the attention of the Media and the Medical Community (Stone J., 2020; Hopkins C, 2020). A recently studied conducted by Leichien and colleagues (2020) described olfactory $(85.6 \%)$ and gustatory $(88 \%)$ dysfunctions of 417 patients with mild to moderate disease. Among these patients that suffer from olfactory alteration, $12.6 \%$ had phantosmia, $32.4 \%$ had parosmia; from the 76 patients that did not suffer from nasal obstruction or rhinorrhea $79.7 \%$ presented anosmia or hyposmia (Lechien J, et al. 2020). It suggests that olfactory neuropathy may play a role in olfactory dysfunction. The short term recovery rate from anosmia or hyposmia was $44 \%$ in 59 cured patients of SARS-CoV-2 infection (Lechien J, et al. 2020).

Patients with SARS-CoV-2 infection can also present with encephalopathy and other changes in their level of consciousness. Recently, three cases of encephalitis associated with SARS-CoV-2 have been described. A study by the Beijing hospital was the first to find the SARS-CoV-2 in a patient's cerebrospinal fluid (CSF). This was a 56-year-old patient, whose genetic sequencing confirmed the 
presence of SARS-CoV-2 in the CSF (Zhou L, et al. 2020). In another case, the patient had encephalopathy and was positive for SARS-CoV-2, although no evidence of the virus particles was found in the CSF (Filatov A, et al 2020).

Newly, Moriguchi T and colleagues (2020) reported a case of Meningitis/Encephalitis, in which the specific SARS-CoV-2 RNA was not detected in the nasopharyngeal swab but was detected in a CSF sample. This was a 24-year-old man with no history of travel. The suspicion of COVID-19 was made due to the patient's poor general condition and altered blood count, as well as a chest CT scan showing a small ground-glass opacity on the right superior lobe and both sides of the inferior lobe. The disease was confirmed by means of the RT-PCR test for SARS-CoV-2, using the nasopharyngeal swab and CSF: samples came negative for nasopharynx and positive for CSF, justifying the condition of the patient (Moriguchi T, et al. 2020). Neurological findings of coronavirus infections also include cases of acute disseminated encephalomyelitis (ADEM) (Ann Yeh E, et al. 2003).

Chronic complications have already have been described in SARS patients, which presented with chronic myalgia, mood and sleep disorders (Moldofsky H, et al. 2011). Organic neurological damage was not described in these patients whatsoever. Chronic complications of coronavirus infection in CNS have already been studied in murine models involving MHS and human coronavirus (HCoVOC43) (Hosking M, 2010; Jacomy H, et al. 2006).

Most recently, Zhao $H$ and colleagues (2020) described the first association of Guillain-Barré syndrome (GBS) \& SARS-CoV-2 infection. This was a 61-year-old woman with a complaint of acute weakness in both legs and severe fatigue. Despite the travel history for Wuhan, no respiratory symptoms were reported. These appeared only 7 days after the onset of Guillain-Barré syndrome symptoms. Oropharyngeal swabs were positive for SARS-CoV-2 by RT-PCR assay (Zhao H, et al. 2020). Hence, COVID-19 appears to assume a parainfectious profile, in which GBS and viral infection occur concurrently, instead of the classic postinfectious profile. Curiously, a similar situation has already been described with GBS \& Zika-virus (Siu R, et al. 2016; ).

\section{Conclusions}

Although COVID-19 is mostly described as lung disease, causing pneumonia, several reports have indicated that patients may also display other symptoms. Here we discuss several CNS related features, referred by several patients, especially at the beginning of the disease. Noteworthy the fact that many patients develop both olfactory and taste loss. This evidences that SARS-CoV-2 is not always confined to the respiratory tract and can also invade the central nervous system, inducing neurological diseases (table 1). 
The involvement of the central nervous system was associated with more severe disease when compared with patients that hadn't CNS involvement (Mao L., et al. 2020). It is known that the neurotropism characteristic involves other human coronaviruses like SARS-CoV (Ding Y, et al. 2004; Xu J, et al. 2005) and HCoV OC43 (Jacomy H, et al. 2006; Ann Yeh E, et al. 2020)

When a viral agent such as SARS-CoV-2, which spreads rapidly and has a potential for neuroinvasion, begins to infect the population worldwide, it is important that the medical and research community be aware of chronic neurological complications; be prepared to respond to previously unexpected complications, as happened in post-epidemic complications of the Zika virus (Nunes M, et al. 2016; Cugola F, et al. 2016; Figueredo C, et al. 2019) and von Economo's famous encephalitis lethargy followed by parkinsonism symptoms in those who survived after Spanish flu pandemic (Lutters B, et al. 2018).

Thus, it is important to prioritize and to individualize the treatment protocols based on the severity of the disease and predominant organ involvement. We recommend that in the presence of ataxia, loss of consciousness, convulsion, status epilepticus, encephalitis, myelitis or neuritis, (Bohmwald et al. 2018; Mao L., et al. 2020) differential diagnosis of COVID-19 should be considered, especially in this moment of "Pandemic Status".

The COVID-2019 outbreak has spread worldwide, so careful surveillance is essential to monitor the disease. The clinical conditions of the patients can worsen really fast, and patients can quickly experience respiratory failure. Symptomatic and respiratory support are the treatment modalities available for COVID-19. Moreover, besides the fact that anosmia may indicate a poor prognosis, whether a long-lasting impairment is observed, it needs to be further addressed. Therefore, a fast and accurate diagnosis is necessary. 


\begin{tabular}{|c|c|c|c|}
\hline \multicolumn{4}{|c|}{ NEUROLOGICAL FINDINGS IN HUMAN CORONAVIRUS INFECTION } \\
\hline & PATHOGENS & CLINICAL MANIFESTATIONS & BIBLIOGRAPHY \\
\hline 1. & $\begin{array}{c}\text { Coronavirus } \\
\text { (HCoV-229E, HCoV- } \\
\text { OC43, } \\
\text { SARS-CoV and } \\
\text { HCoV-OC43) }\end{array}$ & $\begin{array}{l}\text { Acute: Febrile seizures; Convulsi- } \\
\text { ons; Loss of consciousness; Ata- } \\
\text { xia; Anosmia or Hyposmia; En- } \\
\text { cephalomyelitis; Encephalitis; Mye- } \\
\text { litis; Neuritis. Acute Disseminated } \\
\text { Encephalomyelitis (ADEM). } \\
\text { - Chronic: myalgia, mood, and sleep } \\
\text { disorders. }\end{array}$ & $\begin{array}{l}\text { Bohmwald et al. } \\
\text { 2018; Hwang C, } \\
\text { 2006; Ann Yeh E, } \\
\text { et al. } 2003 .\end{array}$ \\
\hline \multirow{3}{*}{2.} & \multirow{3}{*}{$\begin{array}{c}\text { COVID-19 } \\
\text { (SARS-CoV-2) }\end{array}$} & $\begin{array}{l}\text { - CNS: headache, dizziness, impai- } \\
\text { red consciousness, ataxia, acute } \\
\text { cerebrovascular disease, and epi- } \\
\text { lepsy. } \\
\text { - PNS: hypogeusia, anosmia or hy- } \\
\text { posmia, and neuralgia, mainly. } \\
\text { - Muscle injury }\end{array}$ & $\begin{array}{l}\text { Mao L., et al. } 2020 \\
\text { Lechien J, et al. } \\
2020\end{array}$ \\
\hline & & $\begin{array}{l}\text { Encephalopathy with }{ }^{1,3} \text { and without } 2 \\
\text { evidence of the virus in the CNS }\end{array}$ & $\begin{array}{l}\text { 1. Zhou L, et al. } \\
2020 \\
\text { 2. Filatov, A. et al } \\
2020 \\
\text { 3.Moriguchi T, et } \\
\text { al. } 2020\end{array}$ \\
\hline & & Guillain-Barré syndrome & $\begin{array}{l}\text { Zhao H, et al. } \\
2020\end{array}$ \\
\hline
\end{tabular}

Table 1: Summary of neurological manifestations found in coronaviruses infections. In the first line, the general findings of other coronaviruses that infect humans. In the second line, the specific findings of SARS-CoV-2, responsible for COVID-19, which were previously mentioned in this paper. 
Appendix 1 - Authors:

\begin{tabular}{|l|l|l|l|}
\hline NAME & LOCATION & CONTRIBUTION & CONTACT AT: \\
\hline $\begin{array}{l}\text { Isabelle } \\
\text { Bandeira }\end{array}$ & $\begin{array}{l}\text { Universidade } \\
\text { da Região de } \\
\text { Joinville }\end{array}$ & $\begin{array}{l}\text { Design and con- } \\
\text { ceptualized study; } \\
\text { analyzed the data; } \\
\text { drafted the manus- } \\
\text { cript for intellectual } \\
\text { content }\end{array}$ & isabellepbandeira@gma \\
il.com \\
\hline $\begin{array}{l}\text { Marco } \\
\text { Sch- } \\
\text { lindwein }\end{array}$ & $\begin{array}{l}\text { Universidade } \\
\text { da Região de } \\
\text { Joinville }\end{array}$ & $\begin{array}{l}\text { Research project } \\
\text { conception, design, } \\
\text { organization, and } \\
\text { execution. Acquisi- } \\
\text { tions, analysis or } \\
\text { interpretation of the } \\
\text { data }\end{array}$ & mail.com \\
\hline $\begin{array}{l}\text { Leticia Ca- } \\
\text { roline Breis }\end{array}$ & $\begin{array}{l}\text { Universidade } \\
\text { da Região de } \\
\text { Joinville }\end{array}$ & $\begin{array}{l}\text { Research project } \\
\text { conception, design, } \\
\text { organization, and } \\
\text { execution. Acquisi- } \\
\text { tions, analysis or } \\
\text { interpretation of the } \\
\text { data }\end{array}$ & breisleticia@gmail.com \\
\hline $\begin{array}{l}\text { Marcus } \\
\text { Gonçalves }\end{array}$ & $\begin{array}{l}\text { Universidade } \\
\text { da Região de } \\
\text { Joinville }\end{array}$ & $\begin{array}{l}\text { Interpreted the } \\
\text { data; revised the } \\
\text { manuscript for in- } \\
\text { tellectual content }\end{array}$ & lo.com.br \\
\hline $\begin{array}{l}\text { Jean Pierre } \\
\text { Schatz- } \\
\text { mann }\end{array}$ & $\begin{array}{l}\text { Universidade } \\
\text { de São Paulo } \\
\text { (ICB-USP) }\end{array}$ & $\begin{array}{l}\text { Interpreted the } \\
\text { data; revised the } \\
\text { manuscript for in- } \\
\text { tellectual content }\end{array}$ & jeanpierre@usp.br \\
\hline marcusribeirao@yaho- \\
\hline and
\end{tabular}




\section{REFERENCES}

Ann Yeh E, Collins A, Cohen M, Duffner P, Faden H. Detection of Coronavirus in the Central Nervous System of a Child With Acute Disseminated Encephalomyelitis. PEDIATRICS. 2003;113(1):e73-e76.

Arbour N, Day R, Newcombe J, Talbot P. Neuroinvasion by Human Respiratory Coronaviruses. Journal of Virology. 2000;74(19):8913-8921.

Baig A, Khaleeq A, Ali U, Syeda H. Evidence of the COVID-19 Virus Targeting the CNS: Tissue Distribution, Host-Virus Interaction, and Proposed Neurotropic Mechanisms. ACS Chemical Neuroscience. 2020;.

Bleau C, Filliol A, Samson M, Lamontagne L. Brain Invasion by Mouse Hepatitis Virus Depends on Impairment of Tight Junctions and Beta Interferon Production in Brain Microvascular Endothelial Cells. J Virol. 2015;89(19):9896-9908.

Bohmwald K, Gálvez N, Ríos M, Kalergis A. Neurologic Alterations Due to Respiratory Virus Infections. Frontiers in Cellular Neuroscience. 2018;12.

Brann D, Tsukahara T, Weinreb C, Logan D, Datta S. Non-neural expression of SARS-CoV-2 entry genes in the olfactory epithelium suggests mechanisms underlying anosmia in COVID-19 patients. 2020;

Chen T, Wu D, Chen H, et al. Clinical characteristics of 113 deceased patients with coronavirus disease 2019: retrospective study [published correction appears in BMJ. 2020 Mar 31;368:m1295]. BMJ. 2020;368:m1091. Published 2020 Mar 26. doi:10.1136/bmj.m1091

Choi R, Goldstein BJ. Olfactory epithelium: Cells, clinical disorders, and insights from an adult stem cell niche. Laryngoscope Investig Otolaryngol. 2018;3(1):35-42

Cugola F, Fernandes I, Russo F, Freitas B, Dias J, Guimarães K et al. The Brazilian Zika virus strain causes birth defects in experimental models. Nature. 2016;534(7606):267-271.

Dimitrov D. The Secret Life of ACE2 as a Receptor for the SARS Virus. Cell. 2003;115(6):652-653.

Ding Y, He L, Zhang Q, Huang Z, Che X, Hou J et al. Organ distribution of severe acute respiratory syndrome(SARS) associated coronavirus(SARS-CoV) in SARS patients: implications for pathogenesis and virus transmission pathways. The Journal of Pathology. 2004;203(2):622-630.

Doty RL. Systemic diseases and disorders. Handb Clin Neurol. 2019;164:361-387 
Dubé M, Le Coupanec A, Wong A, Rini J, Desforges M, Talbot P. Axonal Transport Enables Neuronto-Neuron Propagation of Human Coronavirus OC43. Journal of Virology. 2018;92(17).

Durrant DM, Ghosh S, Klein RS. The Olfactory Bulb: An Immunosensory Effector Organ during Neurotropic Viral Infections. ACS Chem Neurosci. 2016;7(4):464-469.

Figueiredo C, Barros-Aragão F, Neris R, Frost P, Soares C, Souza I et al. Zika virus replicates in adult human brain tissue and impairs synapses and memory in mice. Nature Communications. 2019;10(1).

Filatov A, Sharma P, Hindi F, Espinosa P. Neurological Complications of Coronavirus Disease (COVID19): Encephalopathy. Cureus. 2020;

Fletcher RB, Das D, Gadye L, et al. Deconstructing Olfactory Stem Cell Trajectories at Single-Cell Resolution. Cell Stem Cell. 2017;20(6):817-830.e8

Gu J, Gong E, Zhang B, Zheng J, Gao Z, Zhong Y et al. Multiple organ infection and the pathogenesis of SARS. Journal of Experimental Medicine. 2005;202(3):415-424.

Gu J, Korteweg C. Pathology and Pathogenesis of Severe Acute Respiratory Syndrome. The American Journal of Pathology. 2007;170(4):1136-1147.

Guan W, Ni Z, Hu Y, Liang W, Ou C, He J et al. Clinical Characteristics of Coronavirus Disease 2019 in China. New England Journal of Medicine. 2020;.

Hoffmann M, Kleine-Weber H, Schroeder S, Krüger N, Herrler T, Erichsen S et al. SARS-CoV-2 Cell Entry Depends on ACE2 and TMPRSS2 and Is Blocked by a Clinically Proven Protease Inhibitor. Cell. 2020;.

Hopkins C, Kumar N. Loss of sense of smell as a marker of COVID-19 infection [Internet]. London: Ear, Nose, and Throat surgery professional membership in the United Kingdom (ENT UK); England, 2020. Available from: https://www.entuk.org/covid-19

Hosking M, Lane T. The Pathogenesis of Murine Coronavirus Infection of the Central Nervous System. Critical Reviews ${ }^{\text {TM }}$ in Immunology. 2010;30(2):119-130.

Huang C, Wang Y, Li X, Ren L, Zhao J, Hu Y et al. Clinical features of patients infected with 2019 novel coronavirus in Wuhan, China. The Lancet. 2020;395(10223):497-506. 
Hulswit R, de Haan C, Bosch B. Coronavirus Spike Protein and Tropism Changes. Coronaviruses. 2016;:29-57.

Hwang C. Olfactory neuropathy in severe acute respiratory syndrome: report of A case. Acta Neurologica Taiwanica. 2006;15(1):26-28.

Jacomy H, Fragoso G, Almazan G, Mushynski W, Talbot P. Human coronavirus OC43 infection induces chronic encephalitis leading to disabilities in BALB/C mice. Virology. 2006;349(2):335-346.

Lechien J, Chiesa-Estomba C, De Siati D, Horoi M, Le Bon S, Rodriguez A et al. Olfactory and gustatory dysfunctions as a clinical presentation of mild-to-moderate forms of the coronavirus disease (COVID-19): a multicenter European study. European Archives of Oto-Rhino-Laryngology. 2020;.

Leung W, To K, Chan P, Chan $\mathrm{H}, \mathrm{Wu} \mathrm{A}$, Lee $\mathrm{N}$ et al. Enteric involvement of severe acute respiratory syndrome-associated coronavirus infection. Gastroenterology. 2003;125(4):1011-1017.

Li W, Zhang C, Sui J, Kuhn J, Moore M, Luo S et al. Receptor and viral determinants of SARS-coronavirus adaptation to human ACE2. The EMBO Journal. 2005;24(8):1634-1643.

Lutters B, Foley P, Koehler P. The centennial lesson of encephalitis lethargica. Neurology. 2018;90(12):563-567.

Mao L, Wang M, Chen S, He Q, Chang J, Hong C et al. Neurological Manifestations of Hospitalized Patients with COVID-19 in Wuhan, China: a retrospective case series study. 2020;.

Moldofsky H, Patcai J. Chronic widespread musculoskeletal pain, fatigue, depression and disordered sleep in chronic post-SARS syndrome; a case-controlled study. BMC Neurology. 2011;11(1).

Morichi S, Kawashima H, loi H, Ushio M, Yamanaka G, Kashiwagi Y et al. Cerebrospinal fluid NOx (nitrite/nitrate) in RSV-infected children with CNS symptoms. Journal of Infection. 2009;59(4):299-301.

Moriguchi T, Harii N, Goto J, Harada D, Sugawara H, Takamino J et al. A first Case of Meningitis/Encephalitis associated with SARS-Coronavirus-2. International Journal of Infectious Diseases. 2020;.

Nunes M, Carlini C, Marinovic D, Neto F, Fiori H, Scotta M et al. Microcephaly and Zika virus: a clinical and epidemiological analysis of the current outbreak in Brazil. Jornal de Pediatria. 2016;92(3):230-240. 
Netland J, Meyerholz DK, Moore S, Cassell M, Perlman S. Severe acute respiratory syndrome coronavirus infection causes neuronal death in the absence of encephalitis in mice transgenic for human ACE2. J Virol. 2008;82(15):7264-7275

Oudit G, Kassiri Z, Jiang C, Liu P, Poutanen S, Penninger J et al. SARS-coronavirus modulation of myocardial ACE2 expression and inflammation in patients with SARS. European Journal of Clinical Investigation. 2009;39(7):618-625.

Perlman S, Evans G, Afifi A. Effect of olfactory bulb ablation on spread of a neurotropic coronavirus into the mouse brain. The Journal of Experimental Medicine. 1990;172(4):1127-1132.

Pinto B, Oliveira A, Singh Y, Jimenez L, Goncalves A, Ogava R et al. ACE2 Expression is Increased in the Lungs of Patients with Comorbidities Associated with Severe COVID-19. 2020;.

Qin C, Zhou L, Hu Z, Zhang S, Yang S, Tao Y et al. Dysregulation of immune response in patients with COVID-19 in Wuhan, China. Clinical Infectious Diseases. 2020;

Raj V, Mou H, Smits S, Dekkers D, Müller M, Dijkman R et al. Dipeptidyl peptidase 4 is a functional receptor for the emerging human coronavirus-EMC. Nature. 2013;495(7440):251-254.

Schildgen O, Glatzel T, Geikowski T, Scheibner B, Simon A, Bindl L et al. Human Metapneumovirus RNA in Encephalitis Patient. Emerging Infectious Diseases. 2005;11(3):467-470.

Siu R, Bukhari W, Todd A, et al. Acute Zika infection with concurrent onset of Guillain-Barre Syndrome. Neurology 2016;87:1623-1624.

Sun D, Li H, Lu X, Xiao H, Ren J, Zhang F et al. Clinical features of severe pediatric patients with coronavirus disease 2019 in Wuhan: a single center's observational study. World Journal of Pediatrics. 2020;.11.

Stone J. There's An Unexpected Loss Of Smell And Taste In Coronavirus Patients [Internet]. Forbes. 2020 [cited31 March 2020]. Available from: https://www.forbes.com/sites/judystone/2020/03/20/ theres-an-unexpected-loss-of-smell-and-taste-in-coronavirus-patients/\#40567ff45101

Wang K, Chen W, Zhou Y, Lian J, Zhang Z, Du P et al. SARS-CoV-2 invades host cells via a novel route: CD147-spike protein. 2020;. 
Wen P, Rao X, Xu L, et al. Cortical Organization of Centrifugal Afferents to the Olfactory Bulb: Monoand Trans-synaptic Tracing with Recombinant Neurotropic Viral Tracers. Neurosci Bull. 2019;35(4):709-723

Xu J, Zhong S, Liu J, Li L, Li Y, Wu X et al. Detection of Severe Acute Respiratory Syndrome Coronavirus in the Brain: Potential Role of the Chemokine Mig in Pathogenesis. Clinical Infectious Diseases. 2005;41(8):1089-1096.

Zhao H, Shen D, Zhou H, Liu J, Chen S. Guillain-Barré syndrome associated with SARS-CoV-2 infection: causality or coincidence?. The Lancet Neurology. 2020;.

Zhou L, Zhang M, Gao J, Wang J. Sars-Cov-2: Underestimated damage to nervous system. Travel Medicine and Infectious Disease. 2020;:101642. 